\title{
Percutaneous occlusion of malignant left atrial appendage in patient with recurrent ischemic stroke
}

\section{(D)Antonia Melada*, DIvona Mustapić, (D) Mijo Meter, (D)Josip Katić, (DViktoria Lišnić, (DZora Sušilović Grabovac, \\ (D)Ante Anić, DDarija Baković Kramarić}

University of Split School of Medicine, University Hospital Centre Split, Split, Croatia
RECEIVED:

February 28, 2019

ACCEPTED:

March 24, 2019

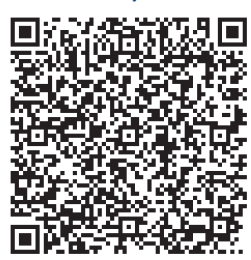

KEYWORDS: left atrial appendage closure, oral anticoagulants, atrial fibrillation, recurrent strokes. CITATION: Cardiol Croat. 2019;14(3-4):91. | https://doi.org/10.15836/ccar2019.91

*ADDRESS FOR CORRESPONDENCE: Antonia Melada, Klinički bolnički centar Split, Spinčićeva 1, HR-21000 Split, Croatia. / Phone: +385-98-225-05 / E-mail: antonia.melada@gmail.com

ORCID: Antonia Melada, https://orcid.org/0000-0003-4223-2582 • Ivona Mustapić, https://orcid.org/0000-0002-1534-3642 Mijo Meter, https://orcid.org/0000-0003-4674-426X • Josip Katić, https://orcid.org/0000-0002-4991-1919 Viktoria Lišnić, https://orcid.org/0000-0001-7598-6749 • Zora Sušilović Grabovac, https://orcid.org/0000-0001-9999-7557 Ante Anić, https://orcid.org/0000-0002-6864-3999 • Darija Baković Kramarić, https://orcid.org/0000-0001-6751-5242

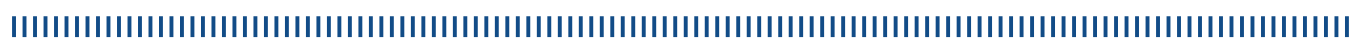

Introduction: The left atrial appendage (LAA) is the most common place of thrombosis in patients with atrial fibrillation (AF). Numerous studies have shown that oral anticoagulation (OAC) significantly reduces the risk of thromboembolism. However, there are no recommendations regarding how to treat cardioembolic recurrent strokes when patients are well anticoagulated. ${ }^{1-3}$

Case report: 68-years-old male with permanent non-valvular AF, currently taking apixaban, was hospitalized for the second time due to recurrent ischemic cerebrovascular stroke. At the time of his first presentation six months ago, he was well anticoagulated with warfarin (international normalized ratio was 3.56) and have had a $\mathrm{CHA}_{2} \mathrm{DS}_{2}$ VASc score 2 . He had no significant carotid disease or mobile aortic arch atheroma. Transesophageal echocardiography (TEE) revealed a significantly dilated left atrium (LA) with dense spontaneous echo contrast (SEC). There was no organized thrombus in the LA nor in the LAA. The contractile function of the LAA was severely decreased, with peak systolic velocity of $33 \mathrm{~cm} / \mathrm{s}$ on Doppler evaluation. Despite taking effective anticoagulant medications for both times our patient experienced recurrent ischemic stroke and yet again had dense SEC in the LA and LAA. In order to prevent upcoming cardioembolic event, we decided to preform percutaneous LAA closure with Amplatzer Amulet device under TEE guidance. Successful LAA closure was confirmed by color Doppler imaging and a single postocclusion angiography. The patient was discharged with OAC (warfarin) in addition of $100 \mathrm{mg} /$ day of acetylsalicylic acid to prevent thrombus formation on device. Follow up TEE was performed one month after the procedure. Good position of LAA occluding device was confirmed with no evidence of thrombus formation on the left atrial face of the device.

Conclusion: In general, after implantation of LAA occluding device, OAC is not indicated. However combination therapy with indefinite OAC plus LAA closure in patients with AF with recurrent strokes despite good anticoagulation should be considered in order to prevent a new stroke.

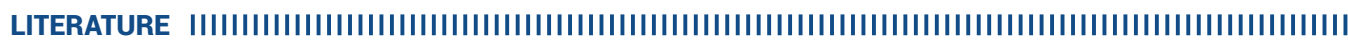

1. Blackshear JL, Odell JA. Appendage obliteration to reduce stroke in cardiac surgical patients with atrial fibrillation. Ann Thorac Surg. 1996 Feb;61(2):755-9. https://doi.org/10.1016/0003-4975(95)00887-X

2. Meier B, Blaauw Y, Khattab AA, Lewalter T, Sievert H, Tondo C, et al; Document Reviewers. EHRA/EAPCI expert consensus statement on catheterbased left atrial appendage occlusion. Europace. 2014 0ct;16(10):1397-416. https://doi.org/10.1093/europace/euu174

3. Masjuan J, Salido L, DeFelipe A, Hernández-Antolín R, Fernández-Golfín C, Cruz-Culebras A, et al. Oral anticoagulation and left atrial appendage closure: a new strategy for recurrent cardioembolic stroke. Eur J Neurol. 2018 Dec 26. doi: 10.1111/ene.13894. [Epub ahead of print]. https://doi.org/10.1111/ene.13894
Cardiologia Croatica $\square$ 2019;14(3-4):91. 